DOI: https://doi.org/10.24127/ajpm.v10i1.3439

\title{
MATHEMATICAL CONNECTION ABILITY BASED ON REFLECTIVE COGNITIVE STYLES
}

\author{
Dita Qondiyana $^{1^{*}}$, Riyadi $^{2}$, Siswanto $^{3}$ \\ ${ }^{1 *, 2,3}$ Mathematics Education, Universitas Sebelas Maret, Indonesia \\ *Corresponding author \\ E-mail: ditaqondiyana@gmail.com ${ }^{\left.{ }^{*}\right)}$ \\ riyadifkipuns@gmail.com $\left.{ }^{2}\right)$ \\ sis.mipa@staff.uns.ac.id $\left.{ }^{3}\right)$
}

Received 30 December 2020; Received in revised form 06 March 2021; Accepted 01April 2021

\begin{abstract}
This research aims to describe students' mathematical connection ability based on their reflective cognitive style. This is a qualitative descriptive research involved eighth graders of State Junior High School of 20 Jambi in the academic year of 2020/2021. The subject was two students determined using purposive sampling technique who represented reflective cognitive style and were in accordance with the teacher's considerations. The essay test material to measure the mathematical connection ability is those that students had learned which are the two-variable linear equation material.The mathematical connection ability test instrument consists of three items, each of which contains one indicator. The test instrument to measure students' reflective cognitive style was the Matching Familiar Figures Test (MFFT) invented by Jerome Kagan. The MFFT instrument in this study was adopted from Warli (2010). The result showed that students' mathematical connection ability viewed from students' reflective cognitive style was in the good category. Students have fulfilled at least two out of three mathematical connection ability indicators: students were able to connect certain topics and other topics. and connect mathematical concept into daily life.
\end{abstract}

Keywords: Mathematics; mathematical connective ability; reflective cognitive style.

\begin{abstract}
Abstrak
Penelitian ini bertujuan untuk mendeskripsikan kemampuan koneksi matematis siswa berdasarkan gaya kognitif reflektif siswa. Metode yang digunakan pada penelitian ini yaitu metode deskriptif kualitatif. Penelitian ini meliputi siswa kelas VIII SMP Negeri 20 Kota Jambi tahun ajaran 2020/2021. Teknik pengambilan subjek menggunakan teknik purposive sampling. Subjek penelitian terdiri dari dua siswa yang mewakili gaya kognitif reflektif dan sesuai dengan pertimbangan guru. Materi tes uraian untuk mengukur kemampuan koneksi matematis adalah materi yang telah dipelajari siswa yaitu materi persamaan linear dua variabel. Intrumen tes kemampuan koneksi matematis terdiri dari tiga butir soal yang mana setiap satu soal memuat satu indikator. Intrumen tes untuk mengukur gaya kognitif reflektif siswa menggunakan Matching Familiar Figures Test (MFFT) yang dicetuskan oleh Jerome Kagan. Instrumen MFFT pada penelitian ini mengadopsi dari Warli (2010). Hasil menunjukkan bahwa kemampuan koneksi matematis siswa ditinjau dari gaya kognitif reflektif siswa dalam kategori baik. Siswa telah memenuhi paling sedikit dua indikator kemampuan koneksi matematis dari pencapain tiga indikator kemampuan koneksi matematis yang harus dipenuhi yaitu siswa dapat menghubungkan konsepkonsep antar topik matematika lainnya dan menghubungkan konsep matematika dalam kehidupan seharihari.
\end{abstract}

Kata kunci: Gaya kognitif reflektif; kemampuan koneksi matematis; matematika.

This is an open access article under the Creative Commons Attribution 4.0 International License 
DOI: https://doi.org/10.24127/ajpm.v10i1.3439

\section{INTRODUCTION}

Mathematics as one of the compulsory subjects in schools play an important role in improving the ability of students to think critically, systematically, logically, creatively, and collaborate effectively because mathematics is a science that has a strong and clear structure and interconnectedness between concepts (Ulfa, 2020). Ability to understand a concept substantially to improve the understanding of mathematical concepts in understanding a mathematical model that describes the relationship between mathematical concepts, data, and situations. This connection is called a mathematical connection ability (Widiyawati et al, 2020).

Mathematical connection ability is a person's ability to present internal and external relationships in mathematics, which includes connections between mathematical topics, connections with other disciplines, and connections in everyday life (Sudirman et al, 2018). According toNational Council of Teacher of Mathematics (NCTM) (2000) mathematical connection ability include; (a) understand the relationship between mathematical ideas, (b) understand how mathematical ideas are related to each other, and (c) use Mathematics outside mathematical context.

There were some research conducted related to mathematical connection ability. One of them is a research by Muflihah et al (2019) the research found that concrete sequential and concrete random thinking style can fulfilled all indicators while abstract sequential and abstract random fulfilled two indicators of mathematical connection ability. Then, students' mathematical connection ability viewed from cognitive style that showed the cognitive of Field Independent cognitive style fulfilled all indicators of students' mathematical connection ability. While Field Dependent only fulfilled one indicator (Sari et al, 2017). The researches only analyzed mathematical connection viewed from thinking style, cognitive style of Field Independent and Field Independent. There was no research discuss about mathematical connection ability viewed from reflective cognitive style.

Based on the field facts, eight graders' mathematical connection ability in Junior High School of 20 Jambi is categorized low since most students still had difficulty in connecting the mathematical interconcept. This is in line with the previous research which claimed that mathematical connection ability of junior high school students was still low. This was indicated by the mathematical connection ability of junior high school students on average of $34 \%$ (Saminanto et al, 2015). The low ability of students' mathematical connections is due to the fact that students are not trained to face real world problems even though they often find them in their daily lives (Bernard et al, 2019).

There are so many concepts in mathematics and they are related each other. One concept becomes a prerequisite for other concepts. Students have different ways of connecting mathematical ideas, so that they can understand learning. In order to understand how students learn, one of them is by paying attention to students' cognitive styles (Prihastanto et al, 2017). Cognitive style is an individual characteristic in the consistent and longlasting use of cognitive functions (thinking, remembering, solving 
problems, making decisions, organizing and processing information, etc.) (Nur et al, 2019).

Different cognitive styles will have an impact on a person's behavior in learning something, especially in education (Lin et al, 2018). Reflective and impulsive cognitive styles are types of cognitive styles. Students who have the characteristics of using a long time to answer problems, but are careful so that the answers are given tend to be correct, are called reflective cognitive styles while students who have characteristics use a short time to solve problems, but are less thorough so that the answers tend to be incorrect, called the impulsive cognitive style (Muhtarom et al, 2018).

To overcome the problem, cognitive style can also influence students' mathematical connection ability. The good cognitive style will contribute to the better mathematical connection ability. The purpose of this research is to determine the mathematical connection ability of eighth graders of junior high school students in the material of two-variable linear equation system in terms of students' reflective cognitive style.

\section{METHOD}

Method used in this research is descriptive qualitative method. This research aims to find out the students' mathematical connection ability viewed from the reflective cognitive style of eight graders of junior high school who learned the material about two-variable linear equation. This research was conducted in Junior High School of 20 Jambi City in the academic year of 2020/2021 by choosing 2 students as the representing the reflective cognitive style group. The research procedure includes preparation, pre-test, research data collection, and reporting. The data used in the research was in the form of answer sheet of cognitive style test, mathematical connection ability test and the result of interview with the research subject.

The resource of data was students who had learnt material about twovariable linear equation. The technique of subject selection used was purposive sampling which aimed to emphasize the special criteria to achieve the research objective in solving research to give the score representative. The subject selection was classified into reflective cognitive style.

The procedure of data collection was conducted by giving the cognitive style test of mathematical connection ability. After calculating the result of students' cognitive style test, the next step was grouped into reflective and impulsive cognitive style. In this research, the subject was students who had reflective cognitive style. The subject selected was as the teacher's recommendation. Then, the subject was interviewed to clarify the result of mathematical connection ability test. In the interview process, the subject was asked to explain the finishing process based on the interview guideline.

Instrument used to collect data was cognitive style test and mathematical connection ability test. Interview guideline was used to obtain connected information between interview and the writing answer of research subject. Interview was conducted openly so that the question can develop based on the field situation. The mathematical connection ability test consisted of 3 essay questions in which each question contained one indicator of Mathematics connection ability. Every indicators of mathematical connection ability has their detail description. The detail 
DOI: https://doi.org/10.24127/ajpm.v10i1.3439

description of Indicators of seen in Table 1. mathematical connection ability can be

Table 1. Indicators of mathematical connection ability

\begin{tabular}{cll}
\hline $\begin{array}{c}\text { No. of } \\
\text { Question }\end{array}$ & \multicolumn{1}{c}{ Indicators } & \multicolumn{1}{c}{ Description } \\
\hline 1 & $\begin{array}{l}\text { Connecting mathematical } \\
\text { concepts in everyday life. } \\
\text { Connecting certain topics } \\
\text { and other topics. }\end{array}$ & $\begin{array}{l}\text { Implementing mathematical relationship in } \\
\text { everyday life. } \\
\text { Implementing the relationship among } \\
\text { mathematical concept. } \\
\text { Connecting the concept of } \\
\text { similar mathematical topic. }\end{array}$ \\
\hline
\end{tabular}

Based on Table 1, it can be seen that mathematical connection ability is consist of 3 kinds of connection. Every kind of connection must be learned by students. The test instrument to measure cognitive style uses the Matching Familiar Figures Test (MFFT) coined by Jerome Kagan. The MFFT instrument in this research was adopted from Warli (2010). The instrument consists of 13 test items. Each test consists of one standard image and 8 variations (stimulus). Between one variation image there is an image that is the same as the raw image. If students answer the correct picture number, they then proceed to the next picture item. If students answer the incorrect number of pictures, they are asked to check again until they find the correct answer. Measurement of the cognitive style required is the time the student answers and the number of student answers to get the correct answer. After obtaining the measurements, they are classified into the reflective cognitive style.

To obtain the valid data, data validity test conducted using method triangulation. The method triangulation was used to check the validity of data or information obtained by researcher in order to minimize the bias.

\section{RESULTS AND DISCUSSION}

The data collection was started by testing students' cognitive style. The result of the test was then grouped into reflective cognitive and impulsive cognitive style. Two students with reflective cognitive style were chosen as subjects in this research. The research subject collection was also done by asking Mathematics teacher's opinion so that the subject will be able to communicate their opinion related to their test answer. The subjects were given three essay questions about twovariable linear equation where each question contains one indicator of mathematical connection ability. The following is the result of students' answer along with the analysis.

\section{Subject 1}

Student did not identify problems coherently such as making what is known and what is asked about and making examples in each written variable. In the first step, student able to model the problem into variable linear equations like student were able to connect the problem topic into mathematical answer by creating mathematical model " $3 x+2 y=$ 69.000 for the equation 1 and $x+2 y=$ 39.000 for the equation 2" although they did not explain each mathematical 
model obtained. In the process, student made mistakes in doing calculations. The final step of the student is wrong in the process, student do not provide solutions to the answers that are asked of the questions.

Based on the results of student interviews, that students understand what is meant by the questions, students can connect the questions into the form of a two-variable linear equation, students realize that they are wrong in doing calculations and students misunderstand the questions from the questions, but students feel able to do it again when given the questions.

This shows that students were able to model problems into equations, but they were mistaken in understanding questions and provide answer solution which was not suitable with the question. Therefore, the student was able to connect mathematical concepts in everyday life. The student answer sheet to question 1 subject 1 is presented in Figure 1.

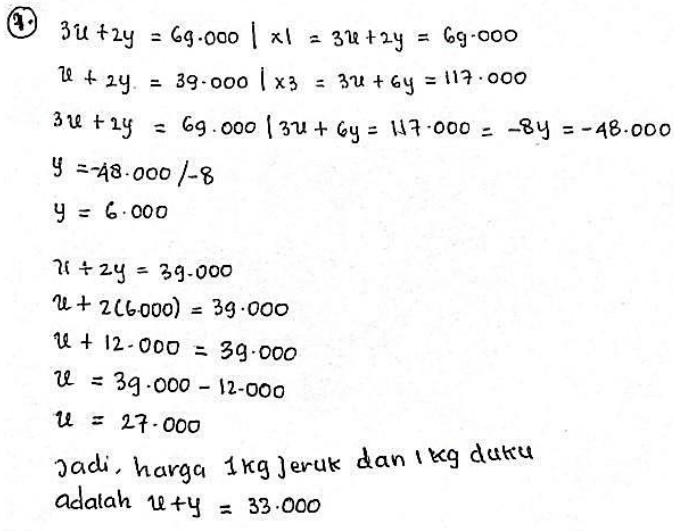

Figure 1. Question 1 Subject 1

Based on the result, student was able to connect between mathematical concepts and applied the concept of rectangles to the concept of twovariable linear equations, for example, students were able to create two variable equation with the rectangular formula "students were able to create equation 1 from the question statements in which the circumference of a farm was $188 \mathrm{~m}$ with the equation $2(p+$ $l)=188$ and equation 2 was $p=18+$ $l "$. Students were able to use substitution method. They provided correct answer solutions even though they did not give clear conclusions.

Based on the results of student interviews, that student understood the solution to these questions, students understood the topic of the problem from what was known and were asked about the questions even though the students did not describe them clearly. According to student, student prefer to work on questions if it has something to do with rectangular material.

This shows that they were able to link concepts and connect certain topics to other topics. The student answer sheet to question 2 subject 1 is presented in Figure 2.

$$
\begin{aligned}
& \text { (2.) } k=188 \quad P=U=\text { ? } \\
& P=18+l \\
& \text { Penye: } k=2(p+l)=188 \\
& p+l=\frac{188}{2} \\
& p+l=94 \\
& (18+l)+l=94 \\
& 2 l=94-18 \\
& l=\frac{76}{2}=38 \mathrm{~m} \\
& p=18+l=18+38=56 m
\end{aligned}
$$

Figure 2. Question 2 Subject 1

Based on the result, the students are correct in modeling mathematical equations even though students use their own way of making equations like "making the Mathematics model of equation $1, \quad x+70=i b n u$ and equation $22 x-30=i b n u$ ', students 
do not make ibnu's example into variable form. Students have understood the concepts being learned, because students are correct in providing completion of the answers requested, even though students do not provide conclusions on the answers needed.

Based on the results of student interviews, that students understand the mathematical concept of the question topic, students are more likely to answer questions in their own way rather than having to coherently such as making known, asked and not being used to creating variable descriptions before creating a mathematical model.

This shows that students can provide solutions to problems because able to connect the concept of similar mathematical topic. The student answer sheet to question 3 subject 1 is presented in Figure 3.

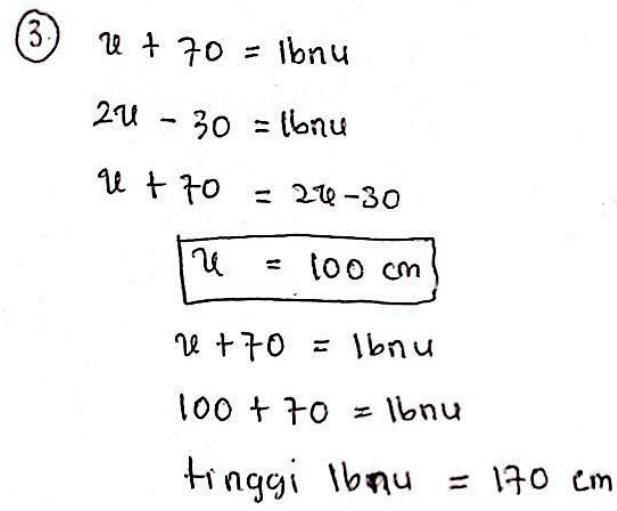

\section{Figure 3. Question 3 Subject 1}

\section{Subject 2}

Student can identify problems correctly. They wrote what they know and are asked about the questions. Students were able to apply mathematical relationships in everyday life like "students were able to make mathematical model from daily life problems with the question statement $3 \mathrm{~kg}$ orange and $2 \mathrm{~kg} d u k u$ is $\mathrm{Rp} 69.000$ became the mathematical model with
$3 x+2 y=69.000$ for equation 1 and equation 2 with the question statement $1 \mathrm{~kg}$ orange and $2 \mathrm{~kg} d u k u$ is $\mathrm{Rp} 39.000$ became the mathematical model with $x+2 y=39.000 "$. This is indicated by students being able to make examples of each variable and create mathematical models and provide conclusions with the correct answers.

Based on the results of student interviews are the students identify coherently by making it known and asked in order to make it easier for students to understand the questions. Students better understand questions when it comes to daily needs, such as determining the price of fruit and determining the price of stationery.

This shows that students were able to connect mathematical concepts in everyday life. The student answer sheet for question 1 subject 2 is presented in Figure 4.

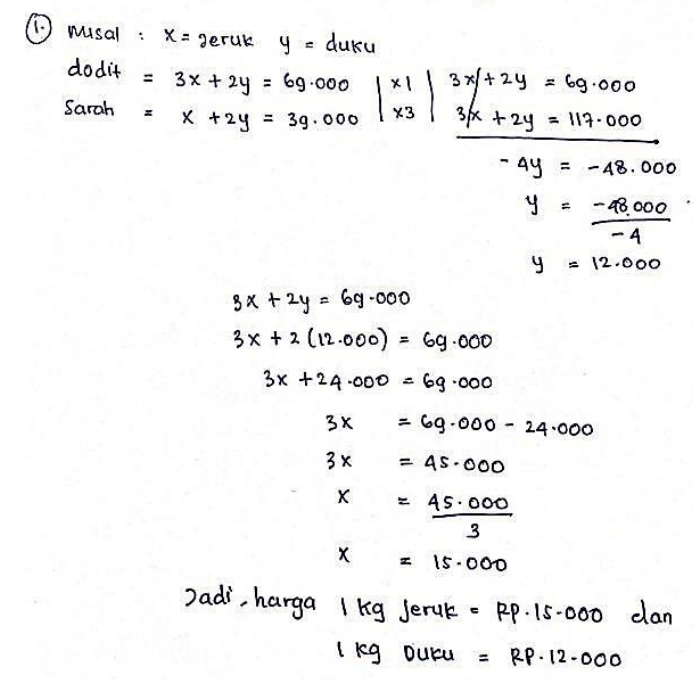

Figure 4. Question 1 Subject 2

Based on the result, student was able to make variable equations correctly like "students were able to make equation 1 from the rectangular formula with $2 p+2 l=188$ and equation 2 with $p=l+18$ " and solve problems coherently along with a summary of the answers to the 
questions asked. Student was able to connect the square concept to determine the length and width into the twovariable linear equation concept correctly, even though they made the calculation to determine the field length value.

Based on the results of student interviews, that student understand these questions and can make variable equations from these question, when interviewed and ask student to be careful about their answers, so that student realize that they were wrong in the counting process, student admit they were wrong and previously they were felt sure that his calculations were correct.

This shows that they were able to connect certain topics and other topics. The student answer sheet to question 2 subject 2 is presented in Figure 5.

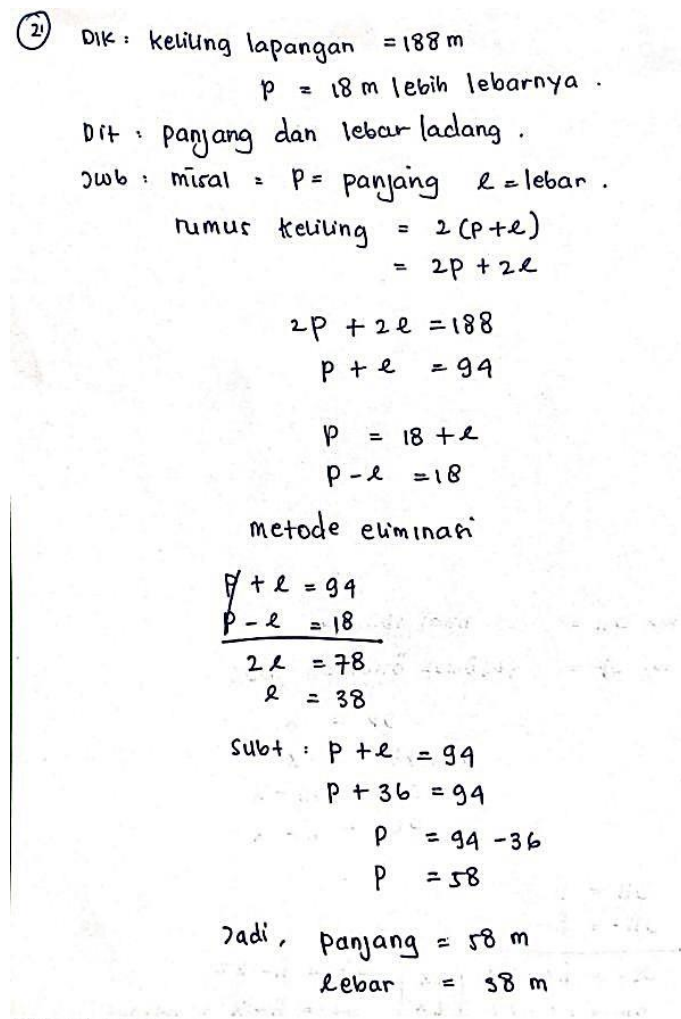

Figure 5. Question 2 Subject 2
Student made examples of the problems given, but they were not correct in making mathematical models and calculation. They did not understand the concept of learning, They were not correct in making the first equation. Students make the first equation, that is $x-y=70$, the correct equation should be, that is $x+y=70$, but they were correct in making the second equation, so that they concluded an incorrect answer.

Based on the results of student interviews, that student is confused when faced with problems such as in question number 3. Student cannot connect the problem topic into the variable equation correctly. Students find it difficult to make mathematical models. Students feel this question is more confusing than the previous problem.

This shows that student can connect the concept of similar mathematical topic. The student answer sheet to question 3 subject 2 is presented in Figure 6.

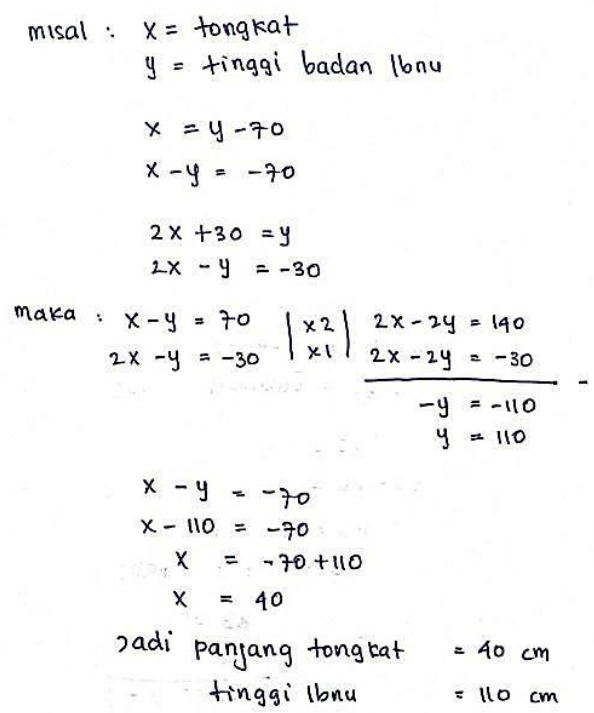

Figure 6. Question 3 Subject 2 
DOI: https://doi.org/10.24127/ajpm.v10i1.3439

Based on the result, the result showed that students' mathematical connection ability can be influenced by the reflective cognitive style. Students with a reflective cognitive style tend to be able to connecting certain topics and other topics, connect mathematical concepts in everyday life, but have not been able to connecting the concept of similar mathematical topic. This is influenced by students' time management in answering the questions. The effective time do not be spent in rush so that they understand the questions well. Actually they need more time to do it, but it was enough that they can be careful so their answers in reflective cognitive questions tend to be correct, and almost all questions fulfilled the indicator accomplishment of mathematical connection ability. This is also influenced by their high curiosity in solving problems that lead them to understand the material deeper.

This is in line with the previous research from (Mahendra et al, 2017) which stated that mathematical connection ability viewed from reflective cognitive style tend to be good, at least three out of five indicators of mathematical connection ability were fulfilled. The similar result also said by (Prihastanto et al, 2017) that subject with reflective cognitive style have fulfilled the whole indicators (three indicators) of mathematical connection ability, reflective subject were able to solve the more simple problem.

Mathematical connection ability viewed from students' reflective cognitive style was chosen in order to find out how far students reflective cognitive style in understanding and processing information to solve problems based on the category grouped into students' reflective cognitive style.
Students' low mathematical connection ability will affect students learning output. This happens since students' mathematical connection ability has an important role in mathematics learning. Therefore, if students' mathematical connection ability is good, they will easily connect every problem into mathematical concept needed and connect mathematical concepts in everyday life.

So the results are in line with mathematical connection ability is considered important because it allows students to connect materials. Students can understand the mathematical concepts they learn because they have mastered the prerequisite materials related to everyday life (Apipah, 2017). According to Kenedi et al (2019) that the ability of mathematical connections is one of the essential things that students must achieve in the learning process because if students know the relationship between concepts, they will quickly understand mathematics and provide opportunities for students to be more can develop mathematical skills. In other words, mathematics is not only memorized but also stick to students' knowledge.

\section{CONCLUSION AND SUGGESTION}

Based on the result and discussion, it can be concluded that students' mathematical connection ability viewed from students' reflective cognitive style was in the good category. Students have fulfilled at least two out of three mathematical connection ability indicators: students were able to connect certain topics and other topics and connect mathematical concept into daily life.

This research is expected to be a reference and comparison for other researchers in dealing with the problems 
of learning mathematics. Suggestion for the next research can be carried out to describe the mathematical connection ability based on other types of cognitive styles and also other materials.

\section{REFERENCES}

Apipah, S., \& Kartono, K. (2017). Analisis Kemampuan Koneksi Matematis Berdasarkan Gaya Belajar Siswa pada Model Pembelajaran Vak dengan Self Assessment. Unnes Journal of Mathematics Education Research 6(2), pp.148-156.

Bernard, M. \& Senjayawati, E. (2019). Meningkatkan Kemampuan Koneksi Matematik Siswa SMP dengan Menggunakan Pendekatan Metaphorical Thinking Berbantuan Software Geogebra. Jurnal Mercumatika: Jurnal Penelitian Matematika dan Pendidikan Matematika 3(2), 2548-1819.

Kenedi, A. K., Helsa, Y., Ariani, Y., Zainil, M., \& Hendri, S. (2019). Mathematical Connection of Elementary School Students to Solve Mathematical Problems. Journal on Mathematics Education 10(1), 2087-8885.

Lin, P. C., Lu, H., \& Lin, Y. C. (2018). A Study of Knowledge Dimension and Cognitive Process Pattern of Cognitive Style Difference in STEM Cooperative Learning Environment. International Journal of Information and Education Technology, 8(10), 720-724.

Mahendra, N. R. \& Mulyono. (2017). Analisis Kemampuan Koneksi Matematis Siswa SMA Ditinjau dari Gaya Kognitif pada Model
PBL. Prosiding Seminar Nasional Matematika 1(1),62-71. Muflihah, I. S., Ratnaningsih, N., Apiati, V. (2019). Analisis Kemampuan Koneksi Matematis Ditinjau Dari Gaya Berpikir Peserta Didik. Journal Authentic Research on Mathematics Education 1(!), 68-77.

Muhtarom., Sugiyanti., Utami, R.E., \& Indriana, K. (2018). Metacognitive ability of male students: difference impulsivereflective cognitive style. $J$. Phys: Conf. Ser.983 012118.

NCTM. (2000). Principle and Standards for School Mathematics. United State of America: NCTM).

Nur, N. \& Yulianti, K. (2019). Analysis Of Mathematics Problem Solving Ability Viewed From Students' Cognitive Style. STEMEIF (Science, Technology, Engineering and Mathematics Learning International Forum).

Prihastanto, A. R. \& Harina, F. (2017). Profil Kemampuan Koneksi Matematis Siswa Smp Yang Bergaya Kognitif ReflektifImpulsif Dalam Menyelesaikan Soal Geometri. Didaktika: Jurnal Pemikiran Matematika 23(2), 2621-8941.

Sari, R. P., Johar, R., \& Hidayat, M. (2020). Kemampuan Koneksi Matematis Siswa pada Materi Bangun Datar melalui Model Meaningful Instructional Design di SMP PKPU Aceh Besar. Jurnal Ilmiah Mahasiswa Pendidikan Matematika 5(1), 5461.

Saminanto. \& Kartono. (2015). Analysis of Mathematical Connection Ability in Linear Equation with One Variable 
DOI: https://doi.org/10.24127/ajpm.v10i1.3439

Based On Connectivity Theory.

International Journal of

Education and Research 3, 259-

270.

Sudirman., Cahyono, E., \& Kadir. (2018). Analisis Kemampuan Koneksi Matematis Siswa SMP Pesisir Ditinjau Dari Perbedaan Gender. Jurnal Pembelajaran Berpikir Matematika 3(2). pp. 11-12.

Ulfa, F. K. (2020). Kemampuan Koneksi Matematis Dan Berpikir Kritis Siswa Dalam Pembelajaran Matematika Melalui Model Brain-Based Learning. Jurnal Pendidikan Matematika 6(2), 106-116.

Widiyawati., Septian, A., \& Inayah, S. (2020). Analisis kemampuan koneksi matematis siswa SMK pada materi trigonometri. Jurnal Analisa 6(1), 28-39. 